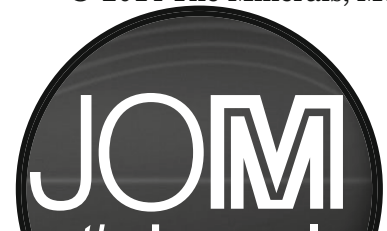
thejournal

\title{
2014 editorial calendar
}

\section{May 2014}

Theme: Metals and Alloys I

- Aluminum: Cast Shop and Alloys

- Phase Transformations in Steels: Processing, Microstructure, and Performance

Manuscripts Due: Deadline Past

\section{June 2014}

\section{Theme: Materials and Processing}

- Polymer and Metal-Matrix Composites

- Materials for Energy Conversion and Storage Technologies

- Powder Materials in Defense, Energy, and Security Systems

- Surface Engineering Materials

- Heterogenous Nucleation and Initial Microstructural Formation

Manuscripts Due: Deadline Past

\section{July 2014 \\ Theme: Modeling}

- Modeling of Magnetic Materials

- Optimization of Metallurgical Reactors: Mathematical and Physical Modeling

- ICME and Modeling of Titanium Alloys

Manuscripts Due: Deadline Past

\section{August 2014}

Theme: Physical Metallurgy

- Aluminum: Shaping and Forming

- Microstructural Patterning during Phase Transformations

- Semisolid Deformation: Experimental and Numerical Developments

- Multiscale Approaches to Hydrogen-Assisted Degradation of Metals

Manuscripts Due: May 1, 2014

\section{September 2014}

Theme: Metals and Alloys II

- Energy Savings in Mining and Metallurgical Industries

- Critical Metals Hydrometallurgy

- Modeling and Simulation of Metallurgical Processes

- Low-Density Steels

- Refractory Metals and Alloys

Manuscripts Due: June 1, 2014

\section{October 2014}

Theme: Mechanical Properties

- Progress in High-Entropy Alloys

- Multi-Objective Optimization for Materials

- Multiscale Perspective of Interface-related Mechanics of Nanocomposites

- Deformation and Forming of Joined Materials

- Multi-scale Modeling: Concurrent and Hierarchical Methods

Manuscripts Due: July 1, 2014

\section{November 2014}

Theme: Energy and Environment

- Aluminum: Recycling and Environmental Issues

- Alloys and Compounds for Thermoelectric and Solar Cell Applications

- Progress with Lead-free Solders

- Critical Materials: Strategies for Achieving Sustainability

Manuscripts Due: August 1, 2014

\section{December 2014}

Theme: Materials for Extreme Environments

- High-Temperature Coatings for Environmental Protection

- Nuclear Applications of ODS and NFA Alloys

- Long-Term Durability of High-Temperature Alloys

- Long-Term Stability of High-Temperature Materials

- Radiation Effects in Oxide Ceramics and Novel LWR Fuels

Manuscripts Due: September 1, 2014 


\section{4 advisors and committees}

Alexis Lewis

Advanced Characterization, Testing, and Simulation Committee

Michael Gao and Sinn-wen Chen Alloy Phases Committee

\author{
Alton Tabereaux \\ Aluminum Committee
}

John Nychka and Jaime Kruzic Biomaterials Committee

\section{Mark Asta}

Chemistry and Physics of Materials Committee

\section{Tomoko Sano}

Composite Materials Committee

\section{Nikhil Gupta}

Composite Materials Committee

Jonathan Zimmerman, Adrian Sabau, Mohsen Asle Zaeem, Mark Tschopp, and Douglas Spearot Computational Materials Science and Engineering Committee

Balasubramaniam Radhakrishnan Computational Materials Science and Engineering Committee

Raul B. Rebak and

Vilupanur A. Ravi

Corrosion \& Environmental Effects Committee

Srinivas Chada

Electronic Packaging \& Interconnection Materials Committee

\author{
Cong Wang \\ Energy Committee
}

\author{
Xiaochuan Lu \\ Energy Conversion and Storage \\ Committee
}

Tim Gabb and Chantal Sudbrack

High Temperature Alloys Committee

Harald Oosterhof

Hydrometallurgy \& Electrometallurgy Committee

Nitin Chopra
ICME Committee

Alok Singh and James Saal

Magnesium Committee

Thomas Woodcock

Magnetic Materials Committee

Shadia Jamil Ikhmayies

Materials Characterization Committee

Brad Boyce, advisor;

Saryu Fensin, guest editor Mechanical Behavior of Materials Committee

Terry Xu and Jung-Kun Lee

Nanomaterials Committee

Jian Wang

Nanomechanical Materials Behavior Committee

Raul Rebak

Nuclear Materials Committee
Yunzhi Wang, advisor; Paul Gibbs, guest editor; Seth Imhoff, guest editor

Phase Transformations Committee

Fernand Marquis

Powder Materials Committee

Lifeng Zhang

Process Technology \& Modeling Committee

Phil Mackey and

Zhiwei Peng

Pyrometallurgy Committee

Gabrielle Gaustad Recycling \& Environmental Technologies Committee

Ridwan Sakidja Refractory Metals Committee

John Carsley Shaping \& Forming Committee

André Phillion Solidification Committee

Sandip Harimkar Surface Engineering Committee

Roger Narayan Thin Films \& Interfaces Committee

William Joost Titanium Committee

Anyone wishing to publish in JOM should follow the guidelines established in the JOM Instructions for Authors. This material features detailed information on communication, manuscript preparation, and publication procedures. The Instructions for Authors are available on the JOM website at www.tms.org.

For More Information Contact:

Telephone: (724) 776-9000 ext. 228

e-mail: jom@tms.org 